\title{
A Laccase with HIV-1 Reverse Transcriptase Inhibitory Activity from the Broth of Mycelial Culture of the Mushroom Lentinus tigrinus
}

\author{
LiJing Xu, ${ }^{1}$ HeXiang Wang, ${ }^{1}$ and TziBun $\mathrm{Ng}^{2}$ \\ ${ }^{1}$ State Key Laboratory for Agrobiotechnology and Department of Microbiology, China Agricultural University, Beijing 100193, China \\ ${ }^{2}$ School of Biomedical Sciences, Faculty of Medicine, The Chinese University of Hong Kong, Shatin, New Territories, Hong Kong
}

Correspondence should be addressed to HeXiang Wang, hxwang1957@gmail.com and TziBun Ng, b021770@mailserv.cuhk.edu.hk

Received 30 November 2011; Accepted 5 January 2012

Academic Editor: Guihua H. Bai

Copyright (c) 2012 Lijing Xu et al. This is an open access article distributed under the Creative Commons Attribution License, which permits unrestricted use, distribution, and reproduction in any medium, provided the original work is properly cited.

\begin{abstract}
A $59 \mathrm{kDa}$ laccase with inhibitory activity against HIV-1 reverse transcriptase $\left(\mathrm{IC}_{50}=2.4 \mu \mathrm{M}\right)$ was isolated from the broth of mycelial culture of the mushroom Lentinus tigrinus. The isolation procedure involved ion exchange chromatography on DEAEcellulose and CM-cellulose, and gel filtration by fast protein liquid chromatography on Superdex 75. The laccase was adsorbed on both types of ion exchangers. About 95 -fold purification was achieved with a $25.9 \%$ yield of the enzyme. The procedure resulted in a specific enzyme activity of $76.6 \mathrm{U} / \mathrm{mg}$. Its $\mathrm{N}$-terminal amino acid sequence was GIPDLHDLTV, which showed little similarity to other mushroom laccase and other Lentinus tigrinus strain laccase. Its characteristics were different from previously reported laccase of other Lentinus tigrinus strain. Maximal laccase activity was observed at a $\mathrm{pH}$ of 4 and at a temperature of $60^{\circ} \mathrm{C}$, respectively. This study yielded the information about the potentially exploitable activities of Lentinus tigrinus laccase.
\end{abstract}

\section{Introduction}

Laccases (benzenediol oxygen oxidoreductase; EC 1.10.3.2) are glycosylated multicopper oxidases. A laccase was first discovered from the Japanese tree Rhus vernicifera more than one century ago [1]. Laccases are widely distributed among plants [2], insects [3], bacteria [4,5], and basidiomycetous and ascomycetous fungi [6-8]. They have been purified from cultured mycelia of various mushrooms [9-13]. In recent years, studies of laccases have been carried out owing to biocatalysts for industrial effluents, bioremediation, colour and phenolic removal, and hair dyeing [14-16].

Proteins with HIV-1 reverse transcriptase inhibitory activities have been purified and characterized from mushrooms including laccase [17-19], antifungal proteins [20], ribonucleases [21], ubiquitin-like peptides [22], and lectins [23].

Lentinus tigrinus is the white rot fungus, which are the most efficient lignin degraders in nature and are capable of producing laccases and ligninolytic peroxidases $[13,24]$.
Hence, most attention has been paid to its lignin-degrading strain, such as the hybrid Mn peroxidase of L. tigrinus 8/18 [25], an efficient PAH degrading strain of L. tigrinus [26], as well as the inducible enzyme including cellulose, xylanases (Elisashvili, Khardziani, Tsiklauri, and Kachlishvili, 1999), Mn peroxidase [25], and laccase [27, 28].

In view of the observation that laccases from other strains (Strain 8/18, Strain CBS 577.79, and Strain BKM F3616D) exhibit different molecular mass and characteristics [29-32], and no attention on its medicinal effects, this prompted us to isolate a laccase with inhibitory activity against HIV-1 reverse transcriptase from the mycelium of the L. tigrinus HPXG59 and compare its characteristics with laccases isolated from other L. tigrinus strains reported earlier.

\section{Materials and Methods}

2.1. Purification and Analysis of Laccase. The mycelium of the mushroom Lentinus tigrinus HPXG59 was incubated at $25^{\circ} \mathrm{C}$ in a shaker for 7 days. The incubation broth was collected 
TABle 1: Purification of laccase from mycelial extract of Lentinus tigrinus.

\begin{tabular}{lccccc}
\hline Chromatographic fractions & Total activity $(\mathrm{U})$ & Total protein content $(\mathrm{mg})$ & Specific laccase activity $(\mathrm{U} / \mathrm{mg})$ & Yield $(\%)$ & Purification fold \\
\hline Extract & 1480.8 & 1828.1 & 0.81 & 100.0 & 1.0 \\
D3 & 939.8 & 89.5 & 10.5 & 63.5 & 13.0 \\
CM2 & 578.3 & 12.6 & 45.9 & 39.1 & 56.7 \\
SU1 & 383.0 & 5.0 & 76.6 & 25.9 & 94.6 \\
\hline
\end{tabular}

and centrifuged $\left(12000 \mathrm{~g}, 20\right.$ minutes, $\left.4^{\circ} \mathrm{C}\right)$. To $500 \mathrm{~mL}$ of the broth, $5.05 \mathrm{~mL}$ of $1 \mathrm{M}$ Tris- $\mathrm{HCl}$ buffer ( $\mathrm{pH} 7.2$ ) was added before ion exchange chromatography of the broth on a $2.5 \times 25 \mathrm{~cm}$ column of DEAE-cellulose (Sigma) in $10 \mathrm{mM}$ Tris-HCl buffer ( $\mathrm{pH}$ 7.2). After the flow through fraction (D1) had been eluted, the column was eluted stepwise with $0.1 \mathrm{M} \mathrm{NaCl}$ and $1 \mathrm{M} \mathrm{NaCl}$ in the starting buffer to yield fractions D2 and D3. Fraction D3 was subsequently subjected to ion exchange chromatography on a $2.5 \times 20 \mathrm{~cm}$ column of $\mathrm{CM}$-cellulose (Sigma) in $10 \mathrm{mM} \mathrm{NH}_{4} \mathrm{OAc}(\mathrm{pH} 4.5)$ when the flow through fraction (CM1) had all been eluted, the column was eluted with a linear concentration $(0-1 \mathrm{M})$ gradient of $\mathrm{NaCl}$ in $10 \mathrm{mM} \mathrm{NH}_{4} \mathrm{OAc}$ buffer ( $\mathrm{pH} 4.5$ ). The first adsorbed fraction (CM2) was then applied to a Superdex 75 HR 10/30 FPLC column (Amersham Biosciences). The column was eluted with $0.2 \mathrm{M} \mathrm{NH}_{4} \mathrm{HCO}_{3}$ buffer ( $\mathrm{pH}$ 8.5). The first peak (fraction SU1) constituted purified laccase.

2.2. Assay of Laccase Activity. Laccase activity was assayed by measuring the oxidation of 2, $7^{\prime}$-azino-bis [3-ethylbenzothiazoline-6-sulfonic acid] diammonium salt (ABTS). A modification of the method of Shin and Lee [40] was used. An aliquot of enzyme solution was incubated in $1.3 \mathrm{~mL}$ of $67 \mathrm{mM}$ sodium acetate buffer ( $\mathrm{pH} 4.5$ ) containing $1.54 \mathrm{mM}$ ABTS at $30^{\circ} \mathrm{C}$. One unit of enzyme activity was defined as the amount of enzyme required to produce an absorbance increase at $40 \mathrm{~nm}$ of one per min per $\mathrm{mL}$ of reaction mixture under the aforementioned conditions.

2.3. Molecular Mass Determination. Molecular mass was determined by sodium dodecyl sulphate-polyacrylamide gel electrophoresis (SDS-PAGE) and FPLC gel filtration. SDSPAGE was carried out in accordance with the procedure of Laemmli and Favre [41], using a 12\% resolving gel and a 5\% stacking gel. At the end of electrophoresis, the gel was stained with Coomassie brilliant blue. FPLC gel filtration in $0.2 \mathrm{M}$ $\mathrm{NH}_{4} \mathrm{HCO}_{3}$ buffer ( $\mathrm{pH} 8.5$ ) at a flow rate of $24 \mathrm{~mL} / \mathrm{h}$ and with a fraction size of $0.8 \mathrm{~mL}$ was carried out using a Superdex 75 column which had been calibrated with molecular mass standards (GE Healthcare).

2.4. Analysis of N-Terminal Amino Acid Sequence. Amino acid sequence analysis was carried out using an HP G1000A Edman degradation unit and an HP1000 HPLC system [20].

2.5. Assay of $\mathrm{pH}$ and Temperature Optima. In the assay for optimal $\mathrm{pH}$ value, a series of solution of ABTS in buffers with different $\mathrm{pH}$ values was used. The assay buffers were prepared in $0.1 \mathrm{M} \mathrm{NaOAc}$ buffer $(\mathrm{pH} 3.0, \mathrm{pH} \mathrm{4.0,} \mathrm{and}$
$\mathrm{pH}$ 5.0), 0.1 M MES buffer ( $\mathrm{pH}$ 5.0, $\mathrm{pH}$ 6.0, and $\mathrm{pH} 7.0$ ) and 0.1 M HEPES buffer ( $\mathrm{pH} 7.0, \mathrm{pH} 8.0$, and $\mathrm{pH} 9.0)$. The assay temperature was $37^{\circ} \mathrm{C}$. To determine the optimal temperature, the reaction mixture was incubated at $20^{\circ} \mathrm{C}$ to $90^{\circ} \mathrm{C}$.

2.6. Assay for HIV-1 Reverse Transcriptase Inhibitory Activity. The assay for HIV reverse transcriptase inhibitory activity was carried out according to instructions supplied with the assay kit from Boehringer Mannheim (Germany). The assay takes advantage of the ability of reverse transcriptase to synthesize DNA, starting from the template/primer hybrid poly (A) oligo (dT) 15. The digoxigenin- and biotin-labeled nucleotides in an optimized ratio are incorporated into one of the same DNA molecule, which is freshly synthesized by the reverse transcriptase (RT). The detection and quantification of synthesized DNA as a parameter for RT activity follows a sandwich ELISA protocol. Biotin-labeled DNA binds to the surface of microtiter plate modules that have been precoated with streptavidin. In the next step, an antibody to digoxigenin, conjugated to peroxidase, binds to the digoxigenin-labeled DNA. In the final step, the peroxidase substrate is added. The peroxidase enzyme catalyzes the cleavage of the substrate, producing a colored reaction product. The absorbance of the samples at $405 \mathrm{~nm}$ can be determined by using a microtiter plate (ELISA) reader and is directly correlated to the level of RT activity. A fixed amount (4-6 ng) of recombinant HIV-1 reverse transcriptase was used. The inhibitory activity of the isolated laccase was calculated as percent inhibition as compared to a control without the laccase [18].

\section{Results and Discussion}

3.1. Purification of Laccase. The mycelial pellet extract of Lentinus tigrinus was fractionated by ion exchange chromatography on DEAE-cellulose. Laccase activity was undetectable in fraction D1, low fraction D2, and concentrated in fraction D3 (Table 1). D3 was resolved on CM-cellulose into a large unadsorbed fraction CM1, a small adsorbed fraction CM2, and a large adsorbed fraction CM3 (Figure 1). Laccase activity was indiscernible in CM1 and mainly located in CM2. Fraction CM3 had very little activity (Table 1). Gel filtration of CM2 yielded two peaks of roughly equal size (collected as fraction SU1 and SU2) together with a small peak SU3 adjacent to SU2 (Figure 2). Laccase activity was enriched in SU1. There was residual activity in SU2 and no activity in SU3 (Table 1). Peak SU1 represented the purified laccase. About 95-fold purification was achieved with a 


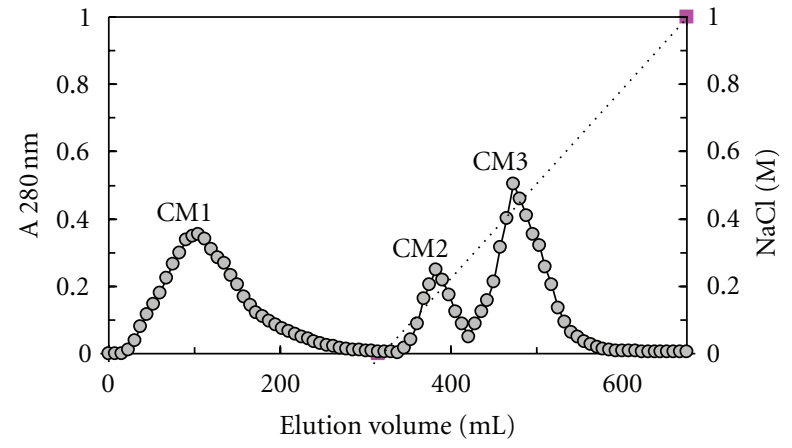

FIGURE 1: Ion exchange chromatography on CM-cellulose column $(2.5 \times 20 \mathrm{~cm})$. Sample: fraction of Lentinus tigrinus incubation broth that was adsorbed on DEAE-cellulose. Fraction size: $8 \mathrm{~mL}$. Starting buffer: $10 \mathrm{mM} \mathrm{NH}_{4} \mathrm{OAc}$ buffer ( $\mathrm{pH} 4.5$ ). Dotted line across right-hand side of chromatogram indicates linear $\mathrm{NaCl}$ concentration (0-1 M) gradient used to CM2 and CM3.

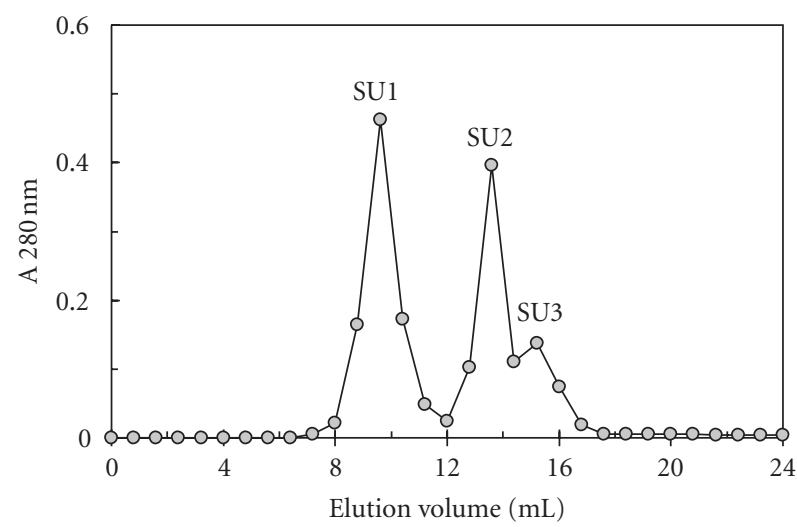

Figure 2: FPLC gel filtration on Superdex 75 hR 10/30 column. Sample: fraction CM2. Buffer: $0.2 \mathrm{M} \mathrm{NH}_{4} \mathrm{HCO}_{3}$ buffer ( $\mathrm{pH} 8.5$ ). Fraction size: $0.8 \mathrm{~mL}$. Flow rate: $0.4 \mathrm{~mL} / \mathrm{min}$.

$25.9 \%$ yield of the enzyme. The purified laccase exhibited an activity of $76.6 \mathrm{U} / \mathrm{mg}$ (Table 1 ).

The chromatographic behavior of Lentinus tigrinus laccase on cationic and anionic exchangers was similar to that of Tricholoma mongolicum laccase [35]. They were both adsorbed on DEAE and CM ion exchangers. But it was differed from laccase from Lentinus edodes [36-38] and other mushrooms $[18,19,42]$ (Table 3 ). The purity was determined by SDS-PAGE. This observation suggests that this enzyme is a monomeric protein (Figure 3).

3.2. Determination of Molecular Mass. SU1 appeared as a single band with a molecular mass of $59 \mathrm{kDa}$ in SDS-PAGE (Figure 3 ) and as a single peak with the same molecular mass upon re-chromatography on Superdex 75 (data not shown). Its molecular mass was close to those of most laccases.

The laccase from L. tigrinus demonstrated a molecular mass of $59 \mathrm{kDa}$, which is less than those $(63 \mathrm{kDa}$ and $69.1 \mathrm{kDa})$ of $L$. tigrinus reported earlier $[29,32,33]$, while it still among the range reported for most other mushroom laccases $[17,35,37-39,43,44]$. A wide range of molecular

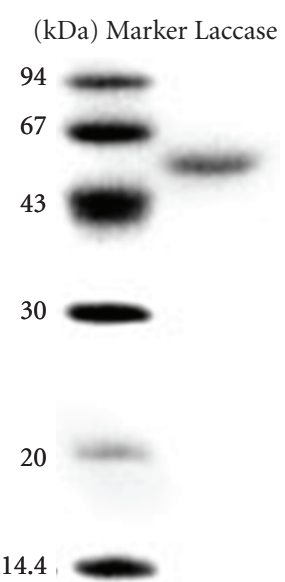

FIGURE 3: Sodium dodecyl sulfate-polyacrylamide gel electrophoresis results. Left lane: molecular mass markers from Ge Healthcare. From top downward: phosphorylase b $(94 \mathrm{kDa})$, bovine serum albumin $(67 \mathrm{kDa})$, ovalbumin $(43 \mathrm{kDa})$, carbonic anhydrase $(30 \mathrm{kDa})$, soybean trypsin inhibitor $(20 \mathrm{kDa})$, and $\alpha$-lactalbumin $(14.4 \mathrm{kDa})$. Right lane: purified laccase (fraction SU1).

TABle 2: N-terminal sequence comparison of Lentinus tigrinus laccase and other mushroom laccases.

\begin{tabular}{lc}
\hline Mushroom laccase & N-terminal sequence \\
\hline Lentinus tigrinus (this study) & GIPDLHDLTV \\
Panus tigrinus 8/18 & AVGPVADLTVTNANISPDGF \\
Lentinus edodes L54 laccase & YGQTVSENLFIVN \\
Lentinus edodes SR-1 laccase & AIGPVTDLHIVN \\
Lentinus edodes laccase & AGTSHFADL \\
Trametes versicolor laccase I & AIGPVASLV \\
Trametes versicolor laccase II & GIGPVADLT \\
Trametes versicolor laccase III & GIGPVADLT \\
Tricholoma mongolicum laccase & GIGPVADLYVGNRIL \\
Tricholoma giganteum laccase & DDPQQAVIDD \\
Coriolus hisutus I & AIGPTADLTISNA \\
Coriolus hisutus II & GIGTKANLVI \\
Pycnoporus cinnabarinus laccase & AIGPVADLTLTNA \\
Agaricus bisporus laccase & DTKTFNFDLVNTRLA \\
Pleurotus eryngii laccase & AVGPVLGPDA \\
Pleurotus ostreatus laccase & AIGPTGNMYIVNE \\
Ganoderma lucidum & GQNGDAVP \\
\hline
\end{tabular}

Identical corresponding amino acid residues are underlined.

$\mathrm{N}$-terminal sequence of laccases other than Tricholoma matsutake laccase are taken from reference.

masses from 30 to $70 \mathrm{kDa}$ is demonstrated by laccase from mushroom (Table 3).

3.3. N-Terminal Amino Acid Sequence. The N-terminal amino acid sequence was GIPDLHDLTV. The N-terminal sequence of Lentinus tigrinus laccase showed little similarity to other mushroom laccases (Table 2). The N-terminal sequence of L. tigrinus laccase bears resemblance to published mushroom Trametes versicolor laccase [45]. However, there 


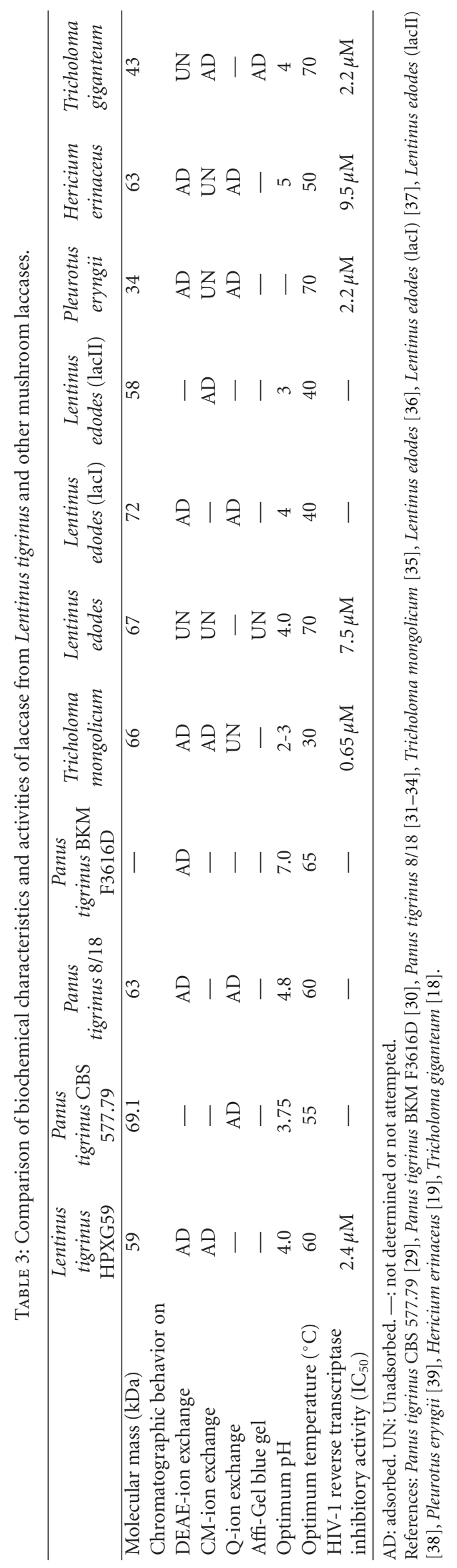




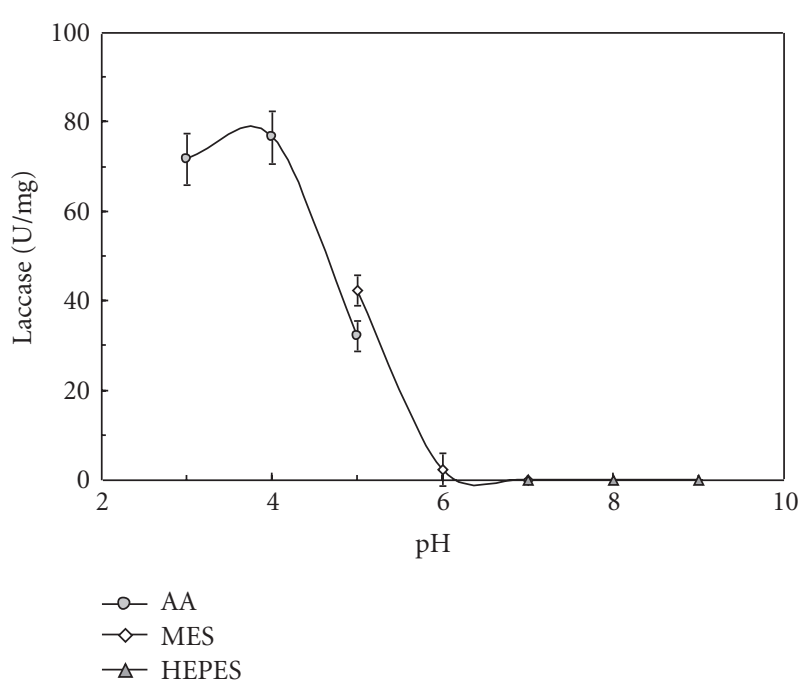

Figure 4: Effect of pH on activity of Lentinus tigrinus laccase.

was only a slight similarity to the $\mathrm{N}$-terminal sequences of $L$. tigrinus reported earlier [32]. It is noteworthy that laccases from different $L$. tigrinus strains may have distinct N-terminal sequence.

3.4. Optimal $p H$ and Temperature. The activity increased slightly as the ambient $\mathrm{pH}$ was elevated to 4 . There was a precipitous decline in activity when the $\mathrm{pH}$ was 5 . Activity was barely detectable at pH 6 and indiscernible at and above pH 7 (Figure 4). The laccase activity rose steadily as the ambient temperature was elevated from $20^{\circ} \mathrm{C}$ to $60^{\circ} \mathrm{C}$. The activity dropped abruptly when the temperature rose to $70^{\circ} \mathrm{C}$. At $100^{\circ} \mathrm{C}$ no activity remained (Figure 5 ).

L. tigrinus laccase requires a temperature of $60^{\circ} \mathrm{C}$ to express maximal activity. In this aspect it resembles laccases from Clitocybe maxima and Tricholoma matsutake which have the optimum temperature at $60^{\circ} \mathrm{C}$. A pH of 4 is optimal for the activity of L. tigrinus laccase requires an acetic $\mathrm{pH}$ for activity, like laccases from a number of mushrooms including Agaricus blazei.

3.5. HIV-1 Reverse Transcriptase Inhibitory Activity. The laccase inhibited HIV-1 reverse transcriptase by $27.7 \%$ and $86.3 \%$ when the laccase concentration was $1.5 \mu \mathrm{M}$ and $15 \mu \mathrm{M}$, respectively. The $\mathrm{IC}_{50}$ value was $2.4 \mu \mathrm{M}$. A comparison of $\mathrm{IC}_{50}$ value towards HIV-1 RT from mushroom laccase is shown in Table 3.

Previously, some mushroom proteins such as laccase [17-19, 35, 36, 42, 43], lectins [46], ubiquitin-like proteins [47], ribosome-inactivating proteins $[20,48]$, and antifungal proteins [20]inhibited the activity of HIV-1 reverse transcriptase. The L. tigrinus laccase also possesses inhibitory activity with an $\mathrm{IC}_{50}$ value around $2.4 \mu \mathrm{M}$. The mechanism of the HIV-1 reverse transcriptase inhibitory activity of the L. tigrinus laccase may be protein-protein interaction [49]. Though some mushroom laccases have shown antiproliferative activity $[17,35,43]$, the L. tigrinus laccase was devoid of antiproliferative and antifungal activities.

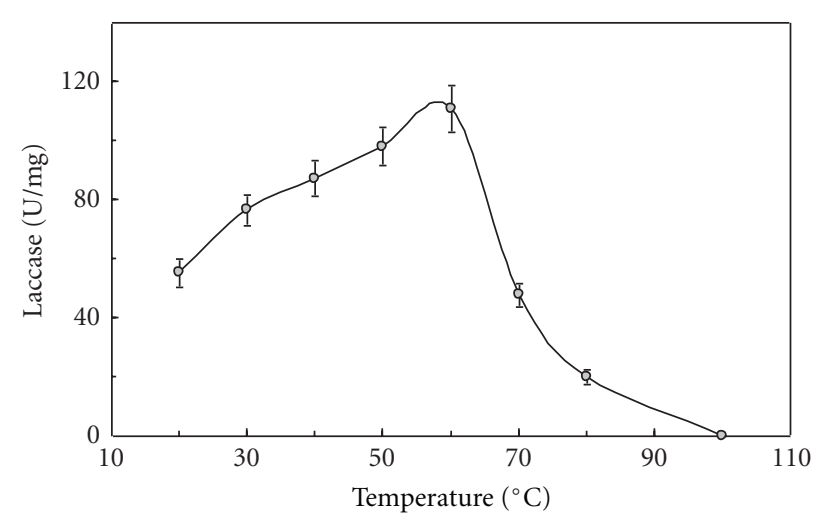

FIGURE 5: Effect of temperature on activity of Lentinus tigrinus laccase.

3.6. Comparison with Other Lentinus tigrinus Laccases. A $64 \mathrm{kDa}$ laccase was purified from both liquid- [32] and solidstate cultures [31] of Panus tigrinus 8/18, using ammonium sulfate, anion exchange on DEAE-Toyopearl 650S, gel filtration on Sephadex G-100, and anion exchange chromatography on a Mono Q column using an FPLC chromatographic system [31]. And the structure of the laccase was solved at $1.5 \AA[50]$.

Another $69.1 \mathrm{kDa}$ laccase was isolated from mycelia of P. tigrinus CBS 577.79, by employing ultrafiltration (cutoff $10 \mathrm{kDa}$ ), chromatography on Q-Sepharose sn Superdex 75 [29]. Cadimaliev has reported a laccase which is isolated by chromatography on TEAE-cellulose and DEAE-Toyopearl $650 \mathrm{M}$ from $P$. tigrinus BKM F3616D [30]. However, its molecular mass and N-sequence has not been described. The laccases isolated by Leontievsky and Golovleva differ from the laccase isolated in the present study and the laccase purified by Daniele Quaratino in biological activities, such as in molecular mass, optimum temperature, and optimum $\mathrm{pH}$ (Table 3). It is hard to compare the $\mathrm{N}$-sequence, since there is no report about the laccase isolated by Leontievsky, Golovleva, and Cadimaliev.

\section{Conclusions}

In summary, the L. tigrinus laccase was found to be different from those of previous laccase in N-terminal sequence, molecular mass, optimal $\mathrm{pH}$, and optimal temperature. The laccase inhibited $\mathrm{HIV}-1$ reverse transcriptase with $\mathrm{IC}_{50}$ value of $2.4 \mu \mathrm{M}$ but was devoid of any antifungal or anti-prolif-er-a-tive activity. Previously isolated L. tigrinus laccases have not been so tested $[29,30,32]$. This study yielded information about the potentially exploitable activities of $L$. tigrinus laccase.

\section{Acknowledgments}

This work was financially supported by the National Grants of China (2010CB732202) and a direct grant from the Medicine Panel of Research Committee, CUHK. 


\section{References}

[1] B. Reinhammar, "Purification and properties of laccase and stellacyanin from Rhus vernicifera," Biochimica et Biophysica Acta, vol. 205, no. 1, pp. 35-47, 1970.

[2] A. M. Mayer and R. C. Staples, "Laccase: new functions for an old enzyme," Phytochemistry, vol. 60, no. 6, pp. 551-565, 2002.

[3] T. L. Hopkins and K. J. Kramer, "Insect cuticle sclerotization," Annual Review of Entomology, vol. 37, no. 1, pp. 273-302, 1992.

[4] G. Alexandre and I. B. Zhulin, "Laccases are widespread in bacteria," Trends in Biotechnology, vol. 18, no. 2, pp. 41-42, 2000.

[5] H. Claus, "Laccases and their occurrence in prokaryotes," Archives of Microbiology, vol. 179, no. 3, pp. 145-150, 2003.

[6] L. L. Kiiskinen, L. Viikari, and K. Kruus, "Purification and characterisation of a novel laccase from the ascomycete $\mathrm{Mel}$ anocarpus albomyces," Applied Microbiology and Biotechnology, vol. 59, no. 2-3, pp. 198-204, 2002.

[7] K. Murugesan, M. Arulmani, I. H. Nam, Y. M. Kim, Y. S. Chang, and P. T. Kalaichelvan, "Purification and characterization of laccase produced by a white rot fungus Pleurotus sajor-caju under submerged culture condition and its potential in decolorization of azo dyes," Applied Microbiology and Biotechnology, vol. 72, no. 5, pp. 939-946, 2006.

[8] K. L. Min, Y. H. Kim, Y. W. Kim, H. S. Jung, and Y. C. Hah, "Characterization of a novel laccase produced by the woodrotting fungus Phellinus ribis," Archives of Biochemistry and Biophysics, vol. 392, no. 2, pp. 279-286, 2001.

[9] G. Palmieri, P. Giardina, L. Marzullo et al., "Stability and activity of a phenol oxidase from the ligninolytic fungus Pleurotus ostreatus," Applied Microbiology and Biotechnology, vol. 39, no. 4-5, pp. 632-636, 1993.

[10] R. P. Bonomo, A. M. Boudet, R. Cozzolino et al., "A comparative study of two isoforms of laccase secreted by the "white-rot" fungus Rigidoporus lignosus, exhibiting significant structural and functional differences," Journal of Inorganic Biochemistry, vol. 71, no. 3-4, pp. 205-211, 1998.

[11] G. Palmieri, P. Giardina, C. Bianco, B. Fontanella, and G. Sannia, "Copper induction of laccase isoenzymes in the ligninolytic fungus Pleurotus ostreatus," Applied and Environmental Microbiology, vol. 66, no. 3, pp. 920-924, 2000.

[12] P. Giardina, V. Aurilia, R. Cannio et al., "The gene, protein and glycan structures of laccase from Pleurotus ostreatus," European Journal of Biochemistry, vol. 235, no. 3, pp. 508-515, 1996.

[13] M. Mansur, M. E. Arias, J. L. Copa-Patiño, M. Flärdh, and A. E. González, "The white-rot fungus Pleurotus ostreatus secretes laccase isozymes with different substrate specificities," Mycologia, vol. 95, no. 6, pp. 1013-1020, 2003.

[14] M. Montazer, F. Dadashian, N. Hemmatinejad, and K. Farhoudi, "Treatment of wool with laccase and dyeing with madder," Applied Biochemistry and Biotechnology, vol. 158, no. 3, pp. 685-693, 2009.

[15] R. S. Teixeira, P. M. Pereira, and V. S. Ferreira-Leitao, "Extraction and application of laccases from shimeji mushrooms (Pleurotus ostreatus) residues in decolourisation of reactive dyes and a comparative study using commercial laccase from Aspergillus oryzae," Enzyme Research, vol. 2010, Article ID 905896, 8 pages, 2010.

[16] M. F. Zhou, X. Z. Yuan, H. Zhong et al., "Effect of biosurfactants on laccase production and phenol biodegradation in solid-state fermentation," Applied Biochemistry and Biotechnology, vol. 164, no. 1, pp. 103-114, 2011.
[17] D. D. Hu, R. Y. Zhang, G. Q. Zhang, H. X. Wang, and T. B. $\mathrm{Ng}$, "A laccase with antiproliferative activity against tumor cells from an edible mushroom, white common Agrocybe cylindracea," Phytomedicine, vol. 18, pp. 374-379, 2011.

[18] H. X. Wang and T. B. Ng, "Purification of a novel low-molecular-mass laccase with HIV-1 reverse transcriptase inhibitory activity from the mushroom Tricholoma giganteum," Biochemical and Biophysical Research Communications, vol. 315, no. 2, pp. 450-454, 2004.

[19] H. X. Wang and T. B. Ng, "A new laccase from dried fruiting bodies of the monkey head mushroom Hericium erinaceum," Biochemical and Biophysical Research Communications, vol. 322, no. 1, pp. 17-21, 2004.

[20] S. K. Lam and T. B. Ng, "First simultaneous isolation of a ribosome inactivating protein and an antifungal protein from a mushroom (Lyophyilum shimeji) together with evidence for synergism of their antifungal effects," Archives of Biochemistry and Biophysics, vol. 393, no. 2, pp. 271-280, 2001.

[21] X. Wu, S. Zheng, L. Cui, H. Wang, and T. B. Ng, "Isolation and characterization of a novel ribonuclease from the pink oyster mushroom Pleurotus djamor," Journal of General and Applied Microbiology, vol. 56, no. 3, pp. 231-239, 2010.

[22] H. X. Wang, H. K. Ngai, and T. B. Ng, "A ubiquitin-like peptide with ribonuclease activity against various polyhomoribonucleotides from the yellow mushroom Cantharellus cibarius," Peptides, vol. 24, no. 4, pp. 509-513, 2003.

[23] H. X. Wang and T. B. Ng, "Examination of lectins, polysaccharopeptide, polysaccharide, alkaloid, coumarin and trypsin inhibitors for inhibitory activity against human immunodeficiency virus reverse transcriptase and glycohydrolases," Planta Medica, vol. 67, no. 7, pp. 669-672, 2001.

[24] L. Bezalel, Y. Hadar, P. P. Fu, J. P. Freeman, and C. E. Cerniglia, "Initial oxidation products in the metabolism of pyrene, anthracene, fluorene, and dibenzothiophene by the white rot fungus Pleurotus ostreatus," Applied and Environmental Microbiology, vol. 62, no. 7, pp. 2554-2559, 1996.

[25] A. V. Lisov, A. A. Leontievsky, and L. A. Golovleva, "Oxidase reaction of the hybrid Mn-peroxidase of the fungus Panus tigrinus 8/18," Biochemistry, vol. 70, no. 4, pp. 467-472, 2005.

[26] S. Covino, M. Čvančarová, M. Muzikář et al., "An efficient PAH-degrading Lentinus (Panus) tigrinus strain: effect of inoculum formulation and pollutant bioavailability in solid matrices," Journal of Hazardous Materials, vol. 183, no. 1-3, pp. 669-676, 2010.

[27] M. Petruccioli, M. Frasconi, D. Quaratino et al., "Kinetic and redox properties of MnP II, a major manganese peroxidase isoenzyme from Panus tigrinus CBS 577.79," Journal of Biological Inorganic Chemistry, vol. 14, no. 8, pp. 1153-1163, 2009.

[28] D. A. Kadimaliev, V. V. Revin, N. A. Atykian, and V. D. Samuilov, "Effect of wood modification on lignin consumption and synthesis of lignolytic enzymes by the fungus Panus (Lentinus) tigrinus," Prikladnaia Biokhimiia i Mikrobiologiia, vol. 39, no. 5, pp. 555-560, 2003.

[29] D. Quaratino, F. Federici, M. Petruccioli, M. Fenice, and A. D'Annibale, "Production, purification and partial characterisation of a novel laccase from the white-rot fungus Panus tigrinus CBS 577.79," Antonie van Leeuwenhoek, vol. 91, no. 1, pp. 57-69, 2007.

[30] D. A. Cadimaliev, V. V. Revin, N. A. Atykyan, and V. D. Samuilov, "Extracellular oxidases of the lignin-degrading fungus Panus tigrinus," Biochemistry, vol. 70, no. 6, pp. 703$707,2005$. 
[31] L. A. Golovleva, A. A. Leontievsky, O. V. Maltseva, and N. M. Myasoedova, "Ligninolytic enzymes of the fungus Panus tigrinus 8/18: biosynthesis, purification and properties," Journal of Biotechnology, vol. 30, no. 1, pp. 71-77, 1993.

[32] A. A. Leontievsky, T. Vares, P. Lankinen et al., "Blue and yellow laccases of ligninolytic fungi," FEMS Microbiology Letters, vol. 156, no. 1, pp. 9-14, 1997.

[33] A. G. Zavarzina, A. A. Leontievsky, L. A. Golovleva, and S. Y. Trofimov, "Biotransformation of soil humic acids by blue laccase of Panus tigrinus 8/18: an in vitro study," Soil Biology \& Biochemistry, vol. 36, no. 2, pp. 359-369, 2004.

[34] D. Quaratino, F. Federici, M. Petruccioli, M. Fenice, and A. D'Annibale, "Production, purification and partial characterisation of a novel laccase from the white-rot fungus Panus tigrinus CBS 577.79," Antonie van Leeuwenhoek, vol. 91, no. 1, pp. 57-69, 2007.

[35] M. Li, G. Zhang, H. Wang, and T. Ng, "Purification and characterization of a laccase from the edible wild mushroom Tricholoma mongolicum," Journal of Microbiology and Biotechnology, vol. 20, no. 7, pp. 1069-1076, 2010.

[36] J. Sun, H. Wang, and T. B. Ng, "Isolation of a laccase with HIV1 reverse transcriptase inhibitory activity from fresh fruiting bodies of the Lentinus edodes (Shiitake mushroom)," Indian Journal of Biochemistry and Biophysics, vol. 48, no. 2, pp. 88 94, 2011.

[37] M. Nagai, T. Sato, H. Watanabe, K. Saito, M. Kawata, and H. Enei, "Purification and characterization of an extracellular laccase from the edible mushroom Lentinula edodes, and decolorization of chemically different dyes," Applied Microbiology and Biotechnology, vol. 60, pp. 327-335, 2002.

[38] M. Nagai, M. Kawata, H. Watanabe et al., "Important role of fungal intracellular laccase for melanin synthesis: purification and characterization of an intracellular laccase from Lentinula edodes fruit bodies," Microbiology, vol. 149, no. 9, pp. 24552462, 2003.

[39] H. X. Wang and T. B. Ng, "Purification of a laccase from fruiting bodies of the mushroom Pleurotus eryngii," Applied Microbiology and Biotechnology, vol. 69, no. 5, pp. 521-525, 2006.

[40] K. S. Shin and Y. J. Lee, "Purification and characterization of a new member of the laccase family from the white-rot basidiomycete Coriolus hirsutus," Archives of Biochemistry and Biophysics, vol. 384, no. 1, pp. 109-115, 2000.

[41] U. K. Laemmli and M. Favre, "Maturation of the head of bacteriophage T4. I. DNA packaging events," Journal of Molecular Biology, vol. 80, no. 4, pp. 575-599, 1973.

[42] H. X. Wang and T. B. Ng, "A novel laccase with fair thermostability from the edible wild mushroom (Albatrella dispansus)," Biochemical and Biophysical Research Communications, vol. 319, no. 2, pp. 381-385, 2004.

[43] G. Q. Zhang, Y. F. Wang, X. Q. Zhang, T. B. Ng, and H. X. Wang, "Purification and characterization of a novel laccase from the edible mushroom Clitocybe maxima," Process Biochemistry, vol. 45, no. 5, pp. 627-633, 2010.

[44] H. X. Wang and T. B. Ng, "A laccase from the medicinal mushroom Ganoderma lucidum," Applied Microbiology and Biotechnology, vol. 72, no. 3, pp. 508-513, 2006.

[45] R. Bourbonnais, M. G. Paice, I. D. Reid, P. Lanthier, and M. Yaguchi, "Lignin oxidation by laccase isozymes from Trametes versicolor and role of the mediator 2,2'-azinobis(3-ethylbenzthiazoline-6-sulfonate) in kraft lignin depolymerization," Applied and Environmental Microbiology, vol. 61, no. 5, pp. 1876-1880, 1995.
[46] H. X. Wang and T. B. Ng, "Examination of lectins, polysaccharopeptide, polysaccharide, alkaloid, coumarin and trypsin inhibitors for inhibitory activity against human immunodeficiency virus reverse transcriptase and glycohydrolases," Planta Medica, vol. 67, no. 7, pp. 669-672, 2001.

[47] H. X. Wang and T. B. Ng, "Isolation of a novel ubiquitinlike protein from Pleurotus ostreatus mushroom with antihuman immunodeficiency virus, translation-inhibitory, and ribonuclease activities," Biochemical and Biophysical Research Communications, vol. 276, no. 2, pp. 587-593, 2000.

[48] H. Wang and T. B. Ng, "Isolation and characterization of velutin, a novel low-molecular-weight ribosome-inactivating protein from winter mushroom (Flammulina velutipes) fruiting bodies," Life Sciences, vol. 68, no. 18, pp. 2151-2158, 2001.

[49] M. Böttcher and F. Grosse, "HIV-1 protease inhibits its homologous reverse transcriptase by protein-protein interaction," Nucleic Acids Research, vol. 25, no. 9, pp. 1709-1714, 1997.

[50] M. Ferraroni, N. M. Myasoedova, V. Schmatchenko et al., "Crystal structure of a blue laccase from Lentinus tigrinus: evidences for intermediates in the molecular oxygen reductive splitting by multicopper oxidases," BMC Structural Biology, vol. 7, article 60, 2007. 

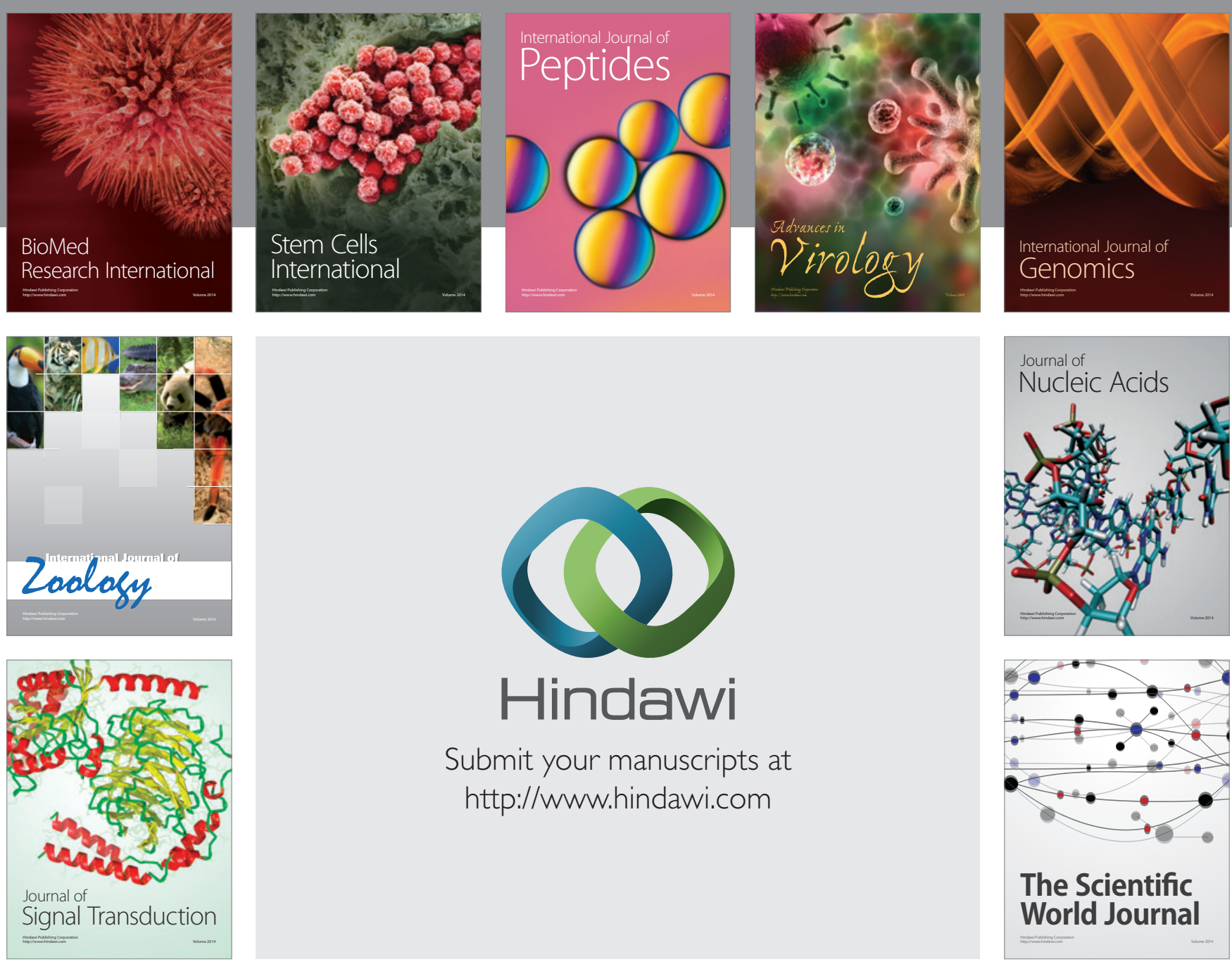

Submit your manuscripts at

http://www.hindawi.com
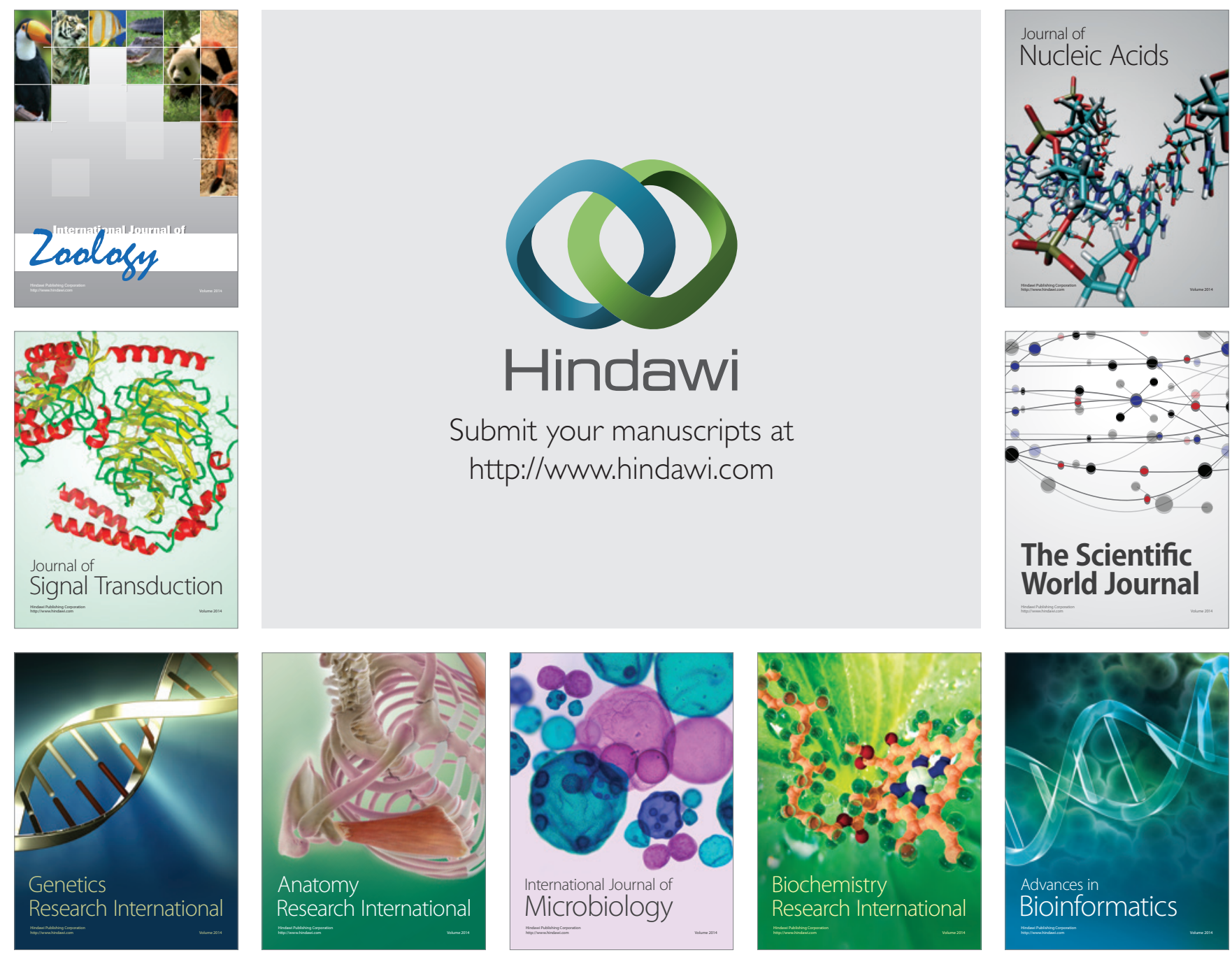

The Scientific World Journal
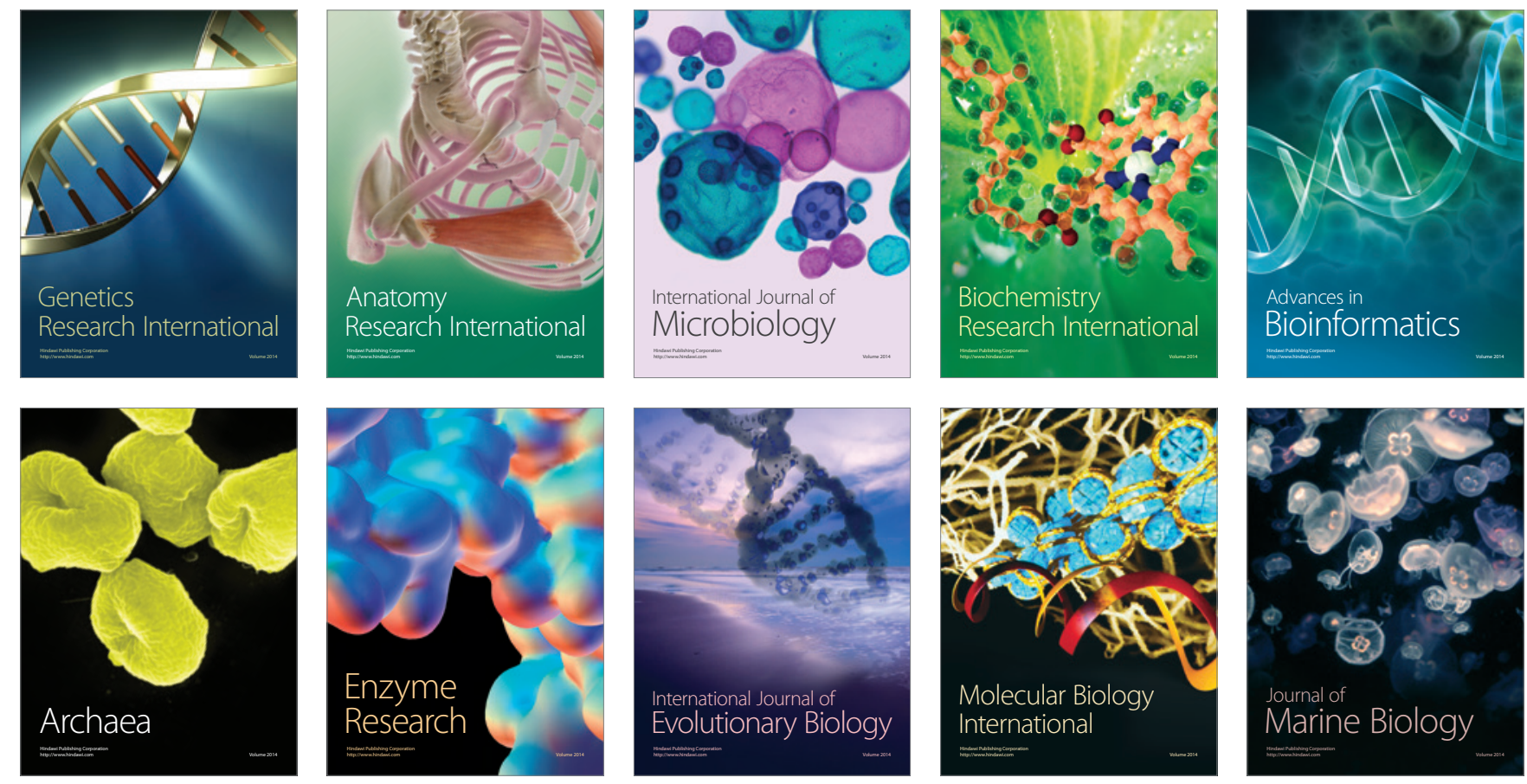